\title{
Test Excavations at Mission San Francisco de la Espada
}

Anne A. Fox

Follow this and additional works at: https://scholarworks.sfasu.edu/ita

Part of the American Material Culture Commons, Archaeological Anthropology Commons, Environmental Studies Commons, Other American Studies Commons, Other Arts and Humanities Commons, Other History of Art, Architecture, and Archaeology Commons, and the United States History Commons

Tell us how this article helped you.

This Article is brought to you for free and open access by the Center for Regional Heritage Research at SFA ScholarWorks. It has been accepted for inclusion in Index of Texas Archaeology: Open Access Gray Literature from the Lone Star State by an authorized editor of SFA ScholarWorks. For more information, please contact cdsscholarworks@sfasu.edu. 


\section{Test Excavations at Mission San Francisco de la Espada}

Creative Commons License

(c) (i) (8)

This work is licensed under a Creative Commons Attribution-NonCommercial 4.0 International License 
TEST EXCAVATIONS AT

MISSION SAN FRAINCISCO DE LA ESPADA

Anne A. Fox

Center for Archaeological Research The University of Texas at San Antonio Archaeological Survey Report, No. 108

1981 
The following information is provided in accordance with General Rules of Practice and Procedure 355.01.00.004, Texas Antiquities Committee:

1. Test Excavations at Mission San Francisco de 1a Espada;

2. Mission San Francisco de la Espada;

3. San Antonio, Bexar County, Texas;

4. Thomas R. Hester, Principal Investigator; Anne A. Fox, Field Director and Author;

5. National Park Service;

6. Texas Historical Commission Antiquities Permit No. 296;

7. Published by the Center for Archaeological Research, The University of Texas at San Antonio, San Antonio, Texas 78285; September 1981。 


\section{ABSTRACT}

In early May 1981, the Center for Archaeological Research, The University of Texas at San Antonio conducted test excavations at Mission de 1a Espada. In an area north of the church, planned for future parking, three test units were excavated to determine the soil stratification and whether construction would impact architectural or cultural features. No indications of such features was found. In an area outside the east wa11, where apparent wa11 foundations appear in aerial photographs, testing revealed that all but a few traces of a structure built in the early 1900s have since been removed. 
TABLE OF CONTENTS

Page

Abstract ...................... . . i

List of Figures. . . . . . . . . . . . . . . ii

Introduction .................... 1

History of the Mission . . . . . . . . . . . . . . . 1

Documentary Research . . . . . . . . . . . . . . 3

Previous Archaeology . . . . . . . . . . . . . . 3

Test Excavations in Area A . . . . . . . . . . . . . . 4

Conclusions for Area A . . . . . . . . . . . . . 6

Test Excavations in Area B . . . . . . . . . . . . 6

Conclusions for Area B.................. 6

Summary and Recommendations. . . . . . . . . . . . . 7

Acknowledgments. . . . . . . . . . . . . . . . 8

References Cited ................... 9

Appendix .................... . 10

\section{LIST OF FIGURES}

Figures

Page

1. Plan of Mission Showing Areas Tested and Excavation Units . . . 2

2. Profile of North Wal1, Test Unit 2. . . . . . . . . 5 


\section{INTRODUCTION}

In April of 1981, the Center for Archaeological Research, The University of Texas at San Antonio, entered into a contract (Change Order No. 1, Contract No. CX702900023) with the National Park Service Southwest Region, to conduct test excavations at Mission San Francisco de la Espada. Two areas ( $A$ and $B$ in Fig. 1) were to be tested. In Area $A$, the stratigraphic sequence and nature of the deposits were to be examined, with special attention to the area along the cemetery wal1. In Area B, the nature, extent and type of construction of wall foundations were to be determined.

Field work was carried out during the period of Apri1 27 to May 6, 1981, and included five test excavations, and clearing and examination of the entire surface of Area B. The site was excavated by stratigraphic layers. A11 measurements were taken in feet and inches, in harmony with the drawings done by Architect Harvey P. Smith. All work was done in accordance with accepted scientific standards, with hand tools only, and a11 excavations were backfilled upon completion.

The crew consisted of the author, Betty Markey and A. J. McGraw. Principal Investigator for the project was Dr. Thomas R. Hester, Director of the Center for Archaeological Research and Jack Eaton, Associate Director, served as CoPrincipal Investigator. Roberta McGregor kindly volunteered her help for one day during the project.

\section{HISTORY OF THE MISSION}

The history of Mission Espada has been recounted in detail by others (Habig 1968:192-233; Winfrey 1965:103-124; Smith 1980:2-18). A brief summary is included to help in understanding the reasons for this particular project.

Mission San Francisco de 1a Espada was moved to San Antonio from east Texas in 1731. The first construction was primarily of wood and thatch, but gradually this was replaced by stone buildings which formed a plaza with the convento and church. The mission was secularized by the early 19th century, after which time it continued to be protection for a group of Spanish and Indian families against the raids of hostile Comanches throughout most of that century. Gradually the population dwindled until there were only a few families living within the mission walls by the turn of the 19th century. The buildings gradually fell into ruins, repaired occasionally by energetic residents or the priests who ministered to the residents of the area. Throughout the years the mission chapel remained the focal point of the surrounding area, continuing the traditional recording of baptism, confirmation, marriage and death of the parishioners. Sometime in the late 19th century burials ceased within the mission cemetery and some of the families began to use a new, private cemetery a short distance away. In the early 20 th century the Sisters of the Incarnate Word started a neighborhood school at the mission. As more space was needed, mission structures on the southeast corner were enlarged to accommodate more pupils. The nuns who taught at the school lived on the mission grounds. 


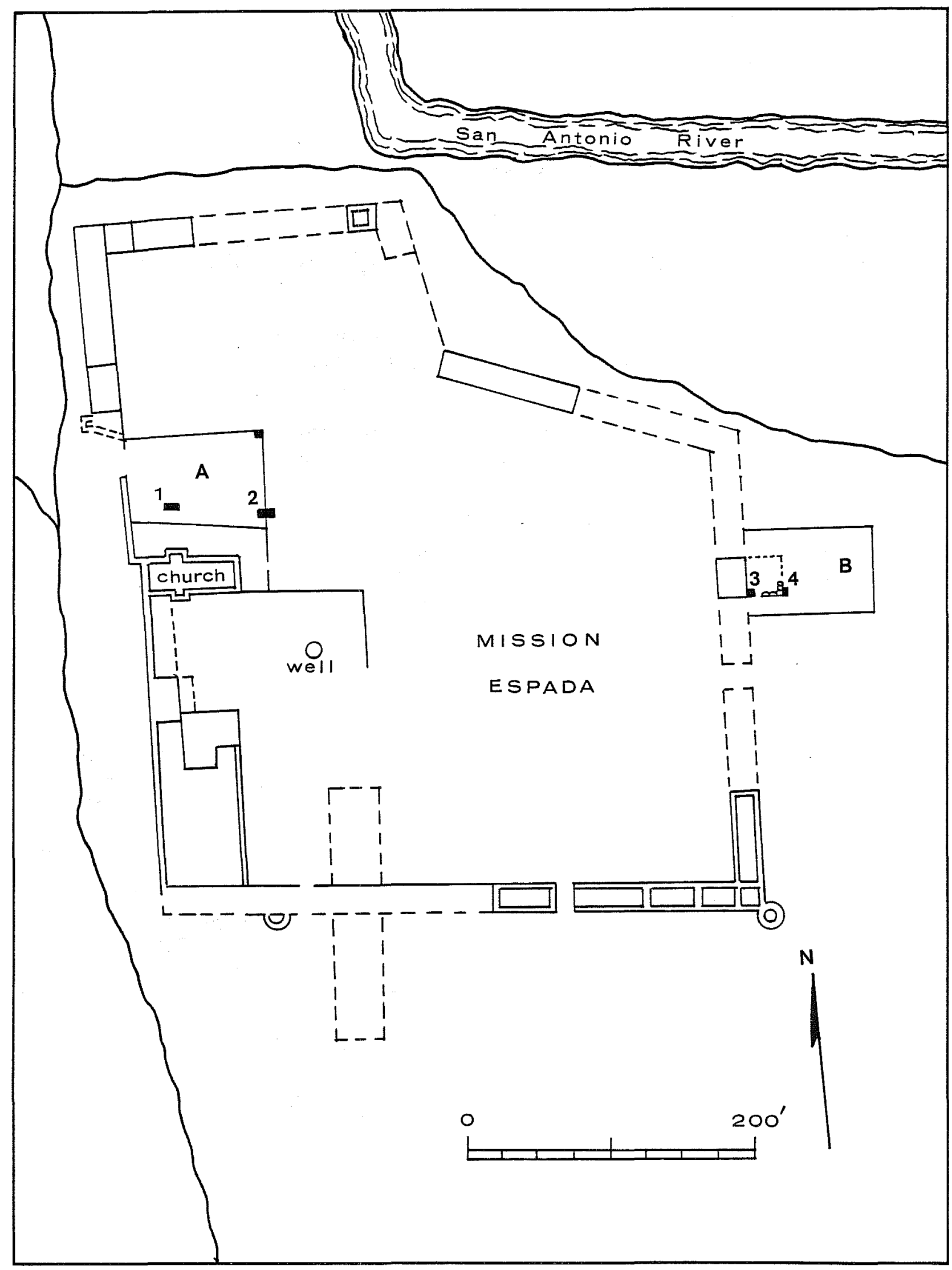

Figure 1. Plan of Mission Showing Areas Tested and Excavation Units. 
Today a small settlement surrounds the mission. Many of the residents grew up in and around the mission, providing a strong feeling of continuity with the past which is a distinctive part of Mission Espada.

\section{DOCUMENTARY RESEARCH}

Previous research plus careful examination of architectural drawings done by Harvey P. Smith and Associates (Smith 1957), indicated that Area A was located just to the north of an enclosure identified by Smith as the cemetery, and that within Area B was a structure identified as the 01d Convent. Later interviews with local residents established that the convent was originally a house built onto the foundations of the east wall of the mission, which was inhabited in the early part of this century by the Oaks family (Ricardo Ramirez, personal communication). When the mission school was initiated in the early 1900s, this residence became the convent for the Sisters of the Incarnate Word who conducted the school. Judging from the Smith map of 1957, referred to above, the New Convent to the east of the mission was in the planning stages at that time. This building is still standing today. It is not presently known when the east portion of the 0ld Convent was torn down or moved away. Today only a few foundation stones remain, although the portion of the Oaks house built upon the mission walls still stands as an unroofed, ruinous one-room structure, with plastered stone walls and a concrete slab floor.

In pursuing the history of burials from the Espada Mission church, we found that informants could not tell us any local tradition of burial within the mission anywhere outside the cemetery, which is outlined by a low stone wall to the north of the church. Sometime around 1900 a new cemetery was opened on land donated by one of the parishioners about $1 / 3$ of a mile west of the compound (Mrs. Rosa Gutierrez, personal communication). This cemetery was located by Fox and Markey during their survey in November 1980 . The earliest marker in this cemetery has a date of death of 1886, but most date from 1900 and later. There are a number of unmarked graves which could also be earlier than 1900.

\section{PREVIOUS ARCHAEOLOGY}

Aside from the work done by Smith in the 1930s, two archaeological investigations have taken place at Espada. In May 1976, the author conducted test excavations at the base of the fortification tower on the southeast corner of the mission prior to repair of that feature (Fox and Hester 1976). During March 1977, Dan Scurlock directed excavation of two 18th century 1ime kilns in the river bank just north of the mission (Killen and Scurlock ms). 


\section{TEST EXCAVATIONS IN AREA A}

Unit 1 was a 50 inch $\times 100$ inch unit laid out 10 feet north of the cemetery wa11 and crossing the point where Smith's (1934, Sheet No. 2) drawings of the results of his excavations indicate a wall continuing toward the north beyond the cemetery. The first layer was excavated to 10 inches through tan, sandy soil which contained a disturbed assortment of artifacts. Once it was determined that the deposit was badly disturbed, it was removed by shovels without screening. At the bottom of this layer was what appeared to be a 2-inch deposit of Spanish Colonial material in darker tan soil. This was screened through 1/4" wire mesh. This deposit rested on sterile, hardpacked soil which was still continuing downward at 12 inches below the surface. A modern pipe trench, which cut through the extreme northeast corner of the unit, was the only intrusion found in the area, and no trace of Smith's wall was found. A deeper test square in the bottom of the unit over the line of Smith's wall showed no indication of disturbance in the area to 19 inches. At this point, photographs were taken and the unit was backfilled.

Unit 2 was a 50 inch $\times 100$ inch unit laid out 10 feet north of the northeast corner of the cemetery, on the line of the east cemetery wall (see Fig. 2). The first excavation level consisted of a dense 3-inch layer of gravel driveway surface, below which were about 3 inches of the same tan, sandy soil encountered in Unit 1, but containing more gravel. Artifacts in this deposit, which was removed, unscreened, with pick and shovel, consisted of bottle glass, bottle caps, and construction debris, probably brought in with the gravel from some other site. Level 2 contained similar tan, sandy soil with gravels embedded, but in addition contained small chunks of adobe. The deposit was highly compacted and contained 19th century artifacts. Within this deposit were two distinct layers of gravel, then a layer of brown sandy soil, then a layer of flat sandstone chunks, which contained numerous bone fragments. In order to insure accurate control of artifact recovery, this level was halted arbitrarily at 15 inches below the surface. Excavation level 3 continued in hard, tan, sandy soil which contained chunks of caliche and variegated patches of dark brown and lighter red-brown soil. Very few artifacts were found in this layer, but there was some charcoal present. Near the bottom, at the southeast and southwest corners of this layer, the red-tan sandy clay subsoil appeared, indicating that the contents of the unit were a part of a disturbance dug into the subsoil. At this point, a 25-inch trench was cut across the center of the unit, on the chance that the disturbance might be a grave pit. However, yellowish clay subsoil was reached at 34 inches without encountering any bone or other artifacts. A peculiar layer of charcoal was found which extended all the way across the unit at ca. 28 inches. No explanation could be found for this feature, and no artifacts were present.

Unit 5 was a 50-inch square unit laid out in the northeast corner of Area $A$, in order to obtain information on stratification away from the immediate cemetery area and away from where Smith's test trenches were located. In this area, the gravel pavement was found to be 7 inches thick. Below this was a thin layer of cultural material lying on sterile, tan sandy soil, which continued to 30 inches, at which point excavation ceased. 

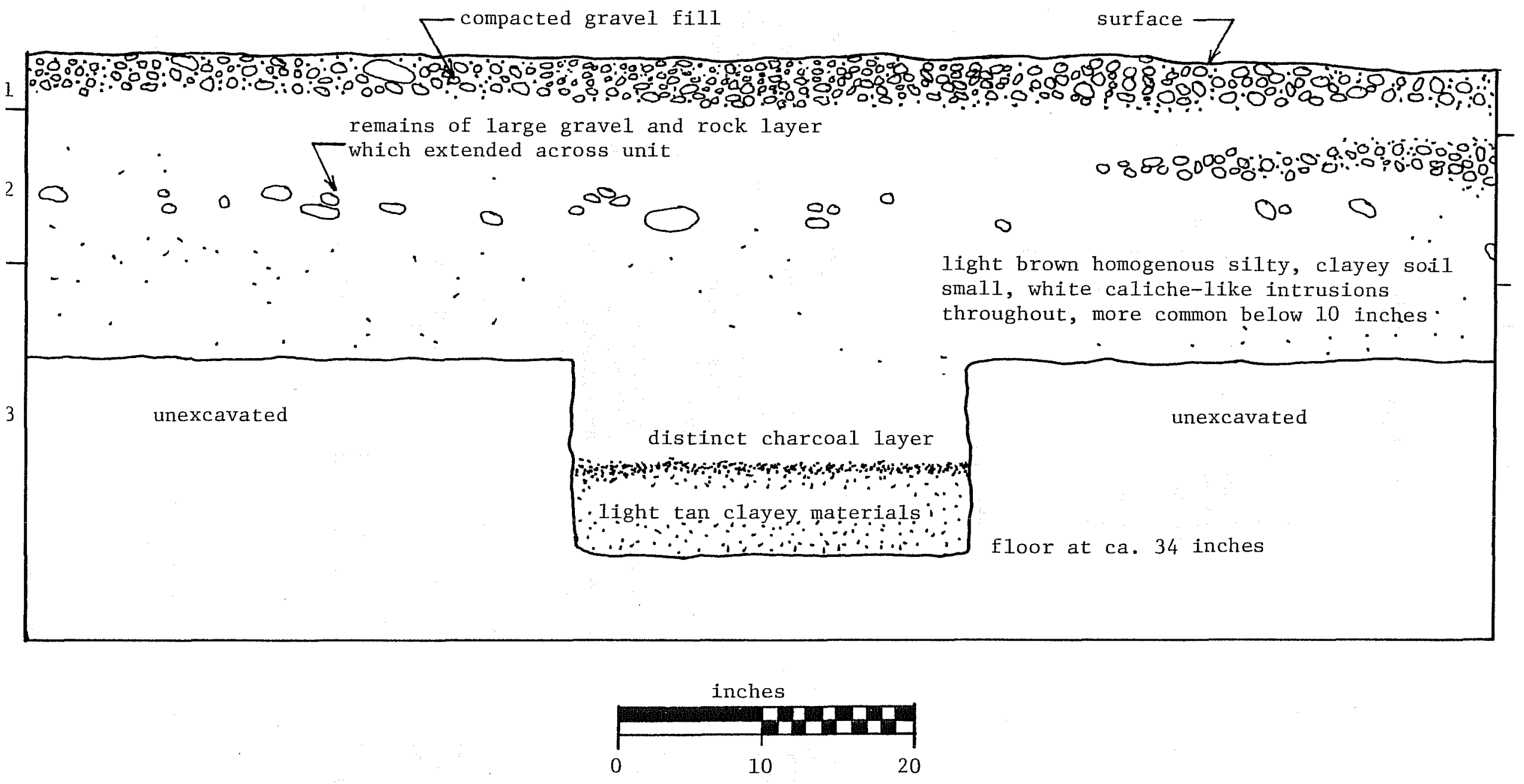

Figure 2. Profile of North wall, Test Unit 2. 
CONCLUSIONS FOR AREA A

It appears that the natural soil in this area is a tan, sandy loam containing small chunks of caliche. In the area of the road and parking lot, several layers of gravel have been applied to the surface over the years and became packed into the surface soil by the action of the vehicles. Just below these gravels is a thin cultural layer which represents the ground surface during the 18th century. We are not able to positively identify the origin of the disturbance which existed throughout Unit 2. It is possible that when the New Cemetery west of the mission was started, some burials were moved there from the 01d Cemetery. However, it seems more likely that the disturbance was a product of Harvey Smith's excavations looking for mission structures in the area in the early 1930s. No trace of human bone or metal artifacts from coffin construction were found in the fill of the unit, and it appears to be rather shallow for a grave. If a burial pit of traditional size had been present, the 50-inch width of the unit would have assured that the edge would show up somewhere in the unit.

\section{TEST EXCAVATIONS IN AREA B}

The surface of the area immediately east of the Oaks house ruins was cleared off and examined. A single line of limestone blocks was found to extend along the south side of the area and turn a corner toward the north at a point 22 feet east of the oaks house wall. Only a few stones on the south wall and on the east wall remain of the original foundation. The ground level slopes rather rapidly toward the river bank in this area, and apparently the rest of the foundation has gradually eroded away or been removed.

Unit 3 was a 24-inch square unit dug through a large pile of fallen wall debris at the junction of the Oaks house with the addition for the convent. No indication was found of the manner of attachment of the addition, and the wall plaster of the Oaks house continued uninterrupted to original ground level on this corner.

Unit 4 was a 14 inch $\times 22$ inch unit laid out east of the southeast corner of the foundation in an attempt to discover the original ground level. A dark brown sandy loam extended from the present ground surface (also the level of the top of the foundation) to a point 7 inches below. Here an ash lense was encountered which contained burned wire nails, egg shells, bones and charcoal pieces. This deposit was 2 inches thick and from there down the dark brown soil was sterile. The foundation stones appear to rest on the top of the ash 1 ayer.

\section{CONCLUSIONS FOR AREA B}

From the documentary and archaeological research, the following history of Area $B$ can be reconstructed. The original, one room structure either is a rebuilding of a remnant of the original mission or a more recent structure 
built in the 19th century on the old foundations and using rock from the mission walls. The mortar is sand and burned lime, typical of mid-19th century Texas stone structures. In fact, the lime was probably prepared in one of the kilns in the river bank not far from the site. At some point in time the 0aks family acquired the house. Apparently Mrs. Oaks outlived her husband, for she is remembered by Mr. Ramirez as living there when he was a child. Sometime between January 27, 1934 when it was not present on Smith's drawings and January 10, 1957 when it was present, an addition was made onto the east side of the house. This may have been done for the Sisters of the Incarnate Word, or it could conceivably have already been there when they began to use the structure. The only photograph we have been able to find of the structure (Gilbert 1949:195) taken from the southeast, shows a shallow porch along the south wall of the addition. Apparently the east wing was of wooden construction, with a simple standing-seam metal roof. According to the photograph, the ground level south of the house was about the same as that of the mission compound, and none of the walls later raised above ground level by Harvey Smith were visible above the surface. The addition was standing in 1957, according to Smith, but was probably razed sometime soon after that when the New Convent was built. Later land clearing and/or erosion have removed a11 traces except for half a dozen foundation stones.

\section{SUMMARY AND RECOMMENDATIONS}

It appears that the cemetery area does not extend farther north than the north wall of the cemetery as shown on Smith's drawings. Although the testing done by the Center crew can hardly be considered a thorough examination of the entire area, we feel reasonably certain in this statement. However, when a new driveway and parking lot are constructed in the area, we suggest that emphas is should be placed on raising the pavement above the present ground level, rather than cutting into it. This will in any case be advisable because of the poor drainage in the area, due to severe compaction of the soil as a result of long use by cars and tour buses. We also would urge that this parking area be built as soon as possible for the large, tour buses are presently seriously damaging the mission grounds in archaeologically-sensitive areas to the east of Area A.

It appears that there is not enough left of the structure of the $01 d$ Convent in Area $B$ to cause any concern in future planning for the area. 


\section{ACKNOWLEDGMENTS}

We wish to acknowledge the kindness and cooperation of Fr. Manuel Ramon, the priest at Mission Espada, who did everything in his power to make our work pleasant and productive. He generously shared information on the history of the mission and the families of his parish, and arranged interviews with knowledgable local residents. We also wish to thank Mr. Ricardo Ramirez for sharing his memories of growing up within the mission walls, and Mrs. Trinidad Herrera and Mrs. Rosa Gutierrez for their patience with our many questions about the local cemetery and its history. We also gratefully acknowledge the help of the staff of the San Antonio Missions National Historic Park, who provided copies of Harvey P. Smith's drawings and H.A.B.S. photographs.

The manuscript was typed by Carme $Y$. Graham and edited by Sharon G. Quirk and Thomas R. Hester. 


\section{REFERENCES CITED}

Fox, A. A. and T. R. Hester

1976 Archaeological Test Excavations at Mission San Francisco de 1 a Espada. Center for Archaeological Research. The University of Texas at San Antonio, Archaeological Survey Report 22.

Gilbert, Rev. M. J., compiler and editor

1949 Archdiocese of San Antonio, Diamond Jubilee, 1874-1949. Schneider Printing Company, San Antonio.

Habig, M. A.

1968 The Alamo Chain of Missions, A History of San Antonio's

Five oed Missions. Franciscan Herald Press, Chicago.

Killen, K. L. and D. Scurlock

ms. A Report on Preliminary Test Excavations at Mission Espada Kilns, San Antonio, Texas. Preliminary Draft. Manuscript on file, Texas Historical Commission, Austin.

Smith, H. P., Sr., A. I. A.

1934 Measured Drawing, Mission San Francisco de 1a Espada, San Antonio, Texas. Sheet No. 2. Copy on file at the Office of San Antonio Missions National Historic Park, San Antonio.

Smith, H. P., and Associates

1957 Site Plan of the San Francisco de la Espada Mission for the Most Rev. Robert E. Lucey, S. T. D., Archbishop of San Antonio Diocese, San Antonio, Texas. January 10, 1957. Copy on file at the Office of San Antonio Missions National Historic Park, San Antonio.

Smith, H. P., Jr.

1980 Espada Mission, Research and Restoration. La Tierra Journal of Southern Texas Archaeological Association $7: 2$.

Winfrey, D. H.

1965 San Francisco de 1a Espada. In Six Missions of Texas. Texian Press, Waco, 103-124. 
APPENDIX

AREA A ARTIFACTS

Unit 1, Layer 1, 0-ca. 10" (disturbed)

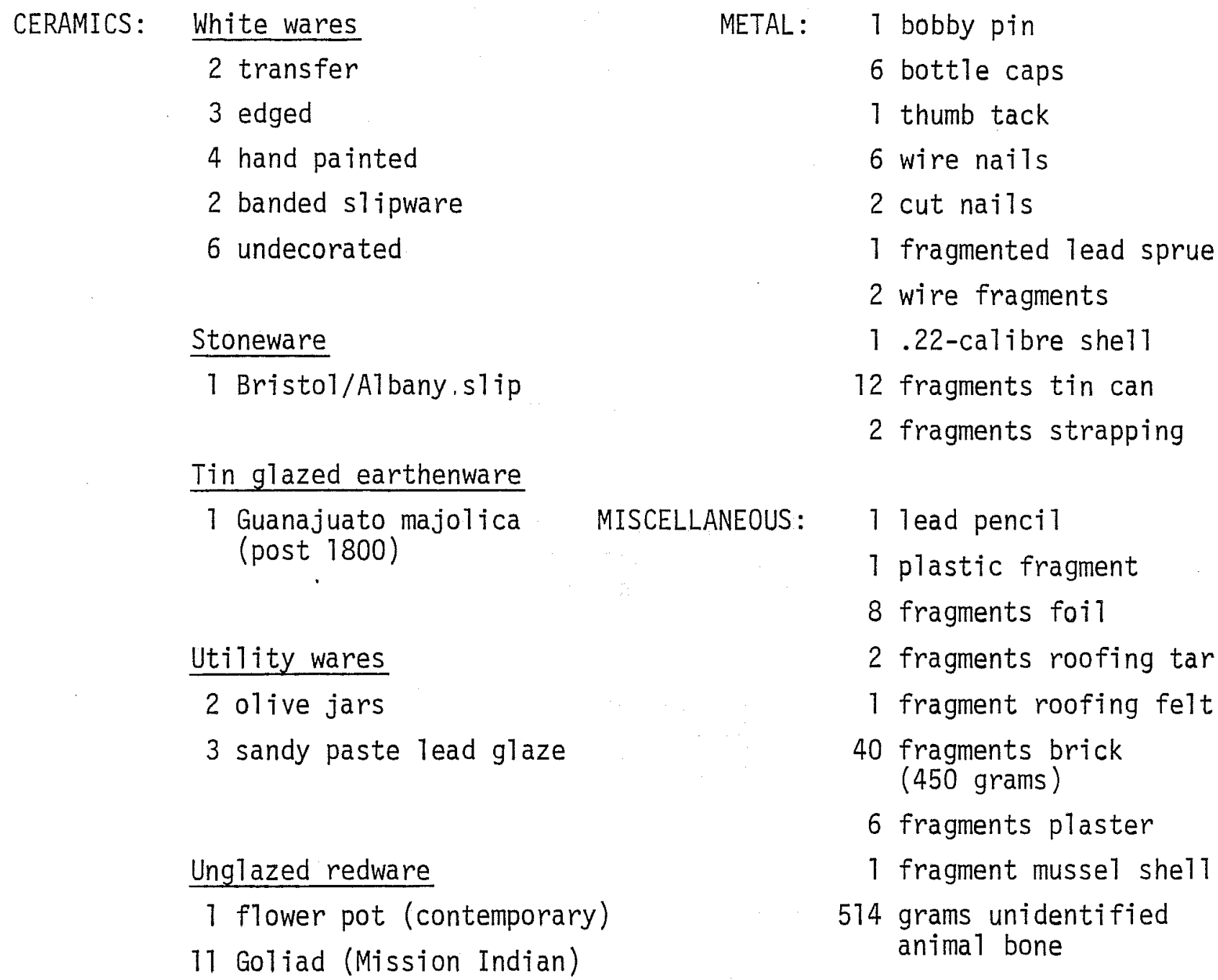

GLASS: $\quad$ Container fragments

11 brown

2 "black"

5 olive

1 bright green

1 olive with gold patina

74 clear

Flat

2 window 
Unit 1, Layer 2, 10"-12"

CERAMICS:

Tin glazed

1 Guanajuato majolica (post 1800)

Lead glazed redware

1 sandy paste

Unglazed

5 Goliad

GLASS:

Container fragments

1 brown

1 clear

METAL: $\quad 1$ fragment sheet copper

MISCELLANEOUS: $\quad 4$ fragments brick (19 grams)

1 fragment plaster

4 fragments chert

59 grams unidentified animal bone

Unit 1, Layer 2, Feature 1 (pipe trench) CERAMICS: White ware

2 undecorated

1 banded slip

Unglazed

1 Goliad

GLASS:

Container fragments

2 clear

1 olive

METAL: $\quad 1$ wire fragment

MISCELLANEOUS: $\quad 3$ fragments brick ( 14 grams)

11 grams unidentified animal bone 
Unit 2, Layer 1, 0-6"

GLASS :

Container fragments

6 clear

2 brown

1 green

Flat

3 window

METAL:

12 fragments tin can

11 crown bottle caps

1 fragment strapping

5 wire nails

4 cut nails

2 fragments wire

MISCELLANEOUS: $\quad 1$ lead tire balancing weight

2 fragments brick (74 grams)

1 fragment composition tile

Unit 2, Layer 2, 6"-75"

CERAMICS:

White wares

2 sponged

Tin glazed

1 blue on white

GLASS: $\quad$ Container fragments

7 green

2 olive

1 brown

1 blue

9 red

4 clear 
Flat

4 window

Bead

1 aqua seed bead

METAL: $\quad 4$ crown bott7e caps

1 unidentified circular object

3 fragments cast iron pot

12 fragments tin can

15 fragments wire

1 unidentified fragment embossed "MABEL-BECKIE"

1 unidentified fragment brass

9 wire nails

13 cut nails

1 horseshoe nail

1 bolt with nut

MISCELLANEOUS: $\quad 1$ fragment musse 1 she 11

3 fragments chert

42 fragments brick

(74 grams)

176 grams unidentified animal bone

Unit 2, Layer 3, 15"-34"

CERAMICS:

1 unglazed

4 Goliad

METAL :

1 tin can fragment

1 cut nail fragment

MISCELLANEOUS: $\quad 2$ fragments chert

1 chert tool

2 fragments unidentified animal bone charcoal sample 
Unit 5, Layer 1, 0-7"

METAL: $\quad 3$ wire nails

1 cut nai1

1 fragment strapping

MISCELLANEOUS: $\quad 1$ shoe hee 1

1 fragment plastic toothbrush

1 fragment brick (110 grams)

Unit 5, Layer 2, 0.7"-30" (cultural materials in 3-4" at top) CERAMICS: Unglazed

2 Goliad

METAL:

3 fragments tin can

1 fragment wire

MISCELLANEOUS: $\quad 1$ fragment chert

95 grams unidentified animal bone

AREA B ARTIFACTS

Unit 3, Layer 1

METAL:

7 wire nails

1 fragment strapping

MISCELLANEOUS:

4 plaster samples (thin plaster over lime stucco, and thin plaster over cement stucco)

25 grams bone (smal1 turtle) 
Unit 4, Layer 1, $0-7^{\prime \prime}$
$\begin{array}{ll}\text { CERAMICS: } & \frac{\text { White wares }}{3 \text { undecorated }} \\ \text { GLASS: } & \frac{\text { Container fragments }}{1 \text { green }} \\ & 1 \text { clear } \\ & 1 \text { alarm clock part } \\ & 6 \text { wire nails } \\ \text { METAL: } & 1 \text { fragment wire } \\ & 1 \text { fragment mussel she11 } \\ & 2 \text { fragments brick } \\ \text { MISCELLANEOUS: } & 16 \text { grams unidentified animal bone }\end{array}$

Unit 4, Layer 2, 0.7"-9"

CERAMICS: White wares

1 undecorated

1 banded slip

METAL: $\quad 17$ wire nails

2 cut nails

MISCELLANEOUS: $\quad 1$ fragment of celluloid decoration

14 fragments egg she 11

6 fragments unidentified burned bone

1 fragment unidentified bone, not burned 
